\title{
THE EASTERN MEADOWLARK IN MANITOBA
}

PETER TAYLOR, P.O. Box 597, Pinawa, Manitoba. R0E 1L0

On the afternoon of 13 June 1981, while driving slowly along a gravel road about $3 \mathrm{~km}$ south and $1 \mathrm{~km}$ east of River Hills, Manitoba $\left(50^{\circ} 3^{\prime}\right.$ N, $96^{\circ}$ $1^{\prime} \mathrm{W}$ ), I was startled to hear the clear, whistled song of the Eastern Meadowlark - so different from the rich melody of the familiar Western species. Stopping abruptly, I soon located the songster on a fence-post just north of the road. It was clearly a meadowlark, but I could not discern the subtle features of plumage that would confirm its identity. After half an hour of observation, I returned home to alert other birders.

This bird was subsequently seen and heard by many experienced observers on several occasions until my last sighting on 13 July. All observations were made within a territory extending about $1 \mathrm{~km}$ north of the gravel road, and about $150 \mathrm{~m}$ on either side of the fence line. The territory included portions of fields of alfalfa and cereal grains. The landowners, Lorne and David Knopf, kindly permitted observers to drive alongside the fence to watch the bird at close quarters. The following notes summarize observations on the bird's plumage, vocalizations and behaviour, and amplify a brief account published elsewhere. ${ }^{7}$ These observations comprise the only documented evidence for the occurrence of the Eastern Meadowlark in Manitoba, although there have apparently been a few unconfirmed sightings. ${ }^{2}$

\section{Plumage}

The most prominent field mark cited by identification guides for distinguishing between Eastern and Western meadowlarks is the extent of yellow on the cheeks. Many guides indicate that the yellow does not extend onto the cheek in the Eastern Meadowlark, whereas it does in the Western. However, Rohwer showed that the situation is less clear-cut. ${ }^{5}$ He measured the "vertical extent of yellow feathers in the mallar region above the submallar apterium" (i.e. onto the cheek) on meadowlark specimens collected in the midwestern United States. Values for Eastern and Western meadowlarks fell within the range 1-4 $\mathrm{mm}$ and 4-10 $\mathrm{mm}$, respectively. The yellow on the River Hills bird certainly did extend onto the cheek; Rudolf Koes and I judged that it resembled a Western Meadowlark in this respect.

Other observations on plumage were hindered by feather wear, especially on the primaries and rectrices. The bird's appearance also varied with different lighting and weather conditions. David Hatch and I independently observed that the bird had a darker brown back, and more heavily marked flight feathers than Western Meadowlarks - consistent with the Eastern species. Koes also noted that the eyeline was very dark and conspicuous, again resembling illustrations of the Eastern bird. However, the streaking on the flanks seemed less heavy and extensive than expected for an Eastern Meadowlark.

\section{Vocalizations}

I noted four general song types. 
Three were variations of the characteristic "tee-yah tee-yair" of the Eastern Meadowlark, with different patterns of inflection but appropriate tone and cadence. The fourth song consisted of an introductory note, then a downward-slurred whistle with Eastern cadence but the modulated tone of the Western species. This character was immediately apparent when tapes were played back to birders who had not yet heard the bird in the field.

David Hatch observed this bird for over two hours on 20 June. ${ }^{2}$ He noted four "good Eastern" song types, and also heard the characteristic, buzzy "dzert" call-note of the Eastern Meadowlark. George Holland made similar observations on 14 June. Hatch, furthermore, believed that two meadowlarks were uttering Eastern calls on 20 and 23 June, while Holland and Martin Siepman also thought that a second bird was present on 27 June.

After a detailed study of the two meadowlark species in Wisconsin, Lanyon concluded that the song is learned, and individuals of one species may occasionally utter the song of the other. ${ }^{4}$ However, the callnote ("dzert"in the Eastern, "chupp" in the Western) appeared to be inherited - or, if learned, it was acquired during the nestling period. Rohwer found that both songs and call-notes were almost invariably uttered appropriately, as indicated by detailed examination of specimens whose calls or song-types had been registered. ${ }^{5}$ Lanyon believed that the "hybrid song", consisting of "phrasing...that is characteristic of the song of the eastern, but the timbre of that of the Western bird", was not a reliable indicator of hybridization, contrary to the assertions of earlier authors he cited. " Rohwer also downplayed the significance of hybrid song. ${ }^{5}$

\section{Behaviour}

At 8 a.m. on 14 June, the River Hills bird responded immediately to a taped Eastern Meadowlark song, recorded in New York state, when played from a car window about 200 m away. ${ }^{3}$ It flew to within $30 \mathrm{~m}$ of the car, and sang vigorously from telephone and fence wires. It also responded to playbacks of Western Meadowlark songs, but only uttered Eastern-type songs in response. Western Meadowlarks in nearby territories responded only to Western Meadowlark playbacks, apparently being unaccustomed to territorial disputes with their Eastern cousins. Both Rohwer and Lanyon found that the two meadowlarks defend territories against either species with similar vigour in regions where they occur sympatrically. ${ }^{4}{ }^{6}$ I observed one territorial encounter between the bird under study and a neighbouring Western Meadowlark. It flew in to challenge the latter bird, which sang from a roadside wire at the southern boundary of the territory described above; the Western Meadowlark drove it away.

On 20 June, Hatch observed an intense encounter between the bird and a second meadowlark. ${ }^{2}$ The birds jumped a metre in the air, fluttering their wings, spreading their tails, stretching their necks and calling frequently. They appeared very similar, and only Eastern calls were heard. Based on Lanyon's descriptions of meadowlark interactions, these observations could refer either to a territorial dispute or an intense courtship display. ${ }^{4}$

\section{Identification}

The observations on vocalization and behaviour leave no doubt that one bird, and likely a second, with Eastern Meadowlark ancestry was present near River Hills in summer 
1981. However, the vexatious question of hybridization should be addressed.

Lanyon observed no mixed pairings among over 100 meadowlark pairs he studied in Wisconsin. ${ }^{4}$ However, he noted that "observations of a mixed pair in Illinois suggest that hybridization may possibly occur at the periphery of the normal breeding range, where pioneering birds are vastly outnumbered by the native species." Such is the case for Eastern Meadowlarks in Manitoba. Lanyon's suggestion was borne out by subsequent records of interbreeding during an eastward range expansion of the Western Meadowlark, as summarized by Rohwer. ${ }^{5}$ The latter author concluded from his muiltivariate analysis of meadowlark specimens that "genetic integrity is being maintained in...areas of sympatry. Nonetheless, certain specimens...fell in phenetic positions highly intermediate... and were presumed to be of mixed ancestry."

In conclusion, although hybridization between these two meadowlarks is a rare event, we can not rule out the possibility that the River Hills birds were hybrids. Conclusive proof of identity would be impossible without detailed examination of a bird in the hand. However, any attempt to trap or collect an individual might have jeopardized the establishment of a breeding population of Eastern Meadowlarks. As luck would have it, this pioneering effort apparently failed, for no further records occurred from 1982 through 1984.

\section{Regional perspective}

Recent records from neighbouring regions to the southeast indicate that the colonization of southeastern Manitoba by Eastern Meadowlarks is not unexpected. Green and Janssen summarize this species' status in Minnesota in summer as follows: "Resident eastward from Lake of the Woods [this county adjoins the Manitoba border], Clearwater and Otter Tail counties in the north, and southward through the middle of the central region to Blue Earth and Faribault counties in the south."1 In personal correspondence, Robert Janssen and Kim Eckert indicated little recent change in the species' status in Minnesota. Eckert informed me of one sighting at Angle Inlet in the Northwest Angle, within $8 \mathrm{~km}$ of the Manitoba border and $100 \mathrm{~km}$ southeast of River Hills, in June 1977. Clive Goodwin, Doug McRae and Alan Wormington informed me of eight different spring and early summer records of Eastern Meadowlarks in extreme northwestern Ontario, mainly near Rainy River, about $50 \mathrm{~km}$ from the southeastern extremity of Manitoba, in 1974-82. The Eastern Meadowlark should therefore be sought by birders in the southeastern corner of Manitoba. In doing so, bear in mind that Eastern Meadowlarks are known to prefer lower-lying, moister habitat than their Western counterparts, although this was not apparent in the River Hills sightings. ${ }^{4} 6$

\section{Acknowledgments}

I am grateful to the following individuals for helpful discussions and correspondence: K.R. Eckert, C.E. Goodwin, D.R.M. Hatch, G.E. Holland, R.B. Janssen, R.F. Koes, R.D. McRae, R.W. Nero, H.A. Ross, A. Wormington and R. Zach.

'GREEN, J.C. and R.B. JANSSEN. 1975. Minnesota birds: where, when, and how many. University of Minnesota Press, Minneapolis.

${ }^{2} \mathrm{HATCH}$, D.R.M. 1981. Meadowlark species sing different, unique songs. Chickadee Notes, Winnipeg Free Press, 26 June. 
${ }^{3}$ KELLOGG, P.P., A.A. ALLEN and R.T. PETERSON. 1971. A field guide to bird songs of Eastern and Central North America (revised). Houghton Mifflin Company, Boston.

${ }^{4}$ LANYON, W.E. 1957. The comparative biology of the meadowlarks (Sturnella) in Wisconsin. Nuttall Ornithological Club Publication No. 1. Cambridge, Massachusetts.

${ }^{5}$ ROHWER, S.A. 1972. A multivariate assessment of interbreeding bet-

\section{VARIED THRUSH IN SASKATOON}

RON JENSEN, 1027 King Crescent, Saskatoon, Saskatchewan.

S7K ON9

Flocks of robins were mobbing the neighbour's Mountain Ash as the migrating birds feasted on overripened fruit. Early frosts and overripe fruit have strange effects on feeding birds; as a result 22 September 1984 was a memorable day!

About two days earlier a Swainson's Thrush had flown into our den window. "Another thrush" were my thoughts upon hearing a thud at the den window. A thrush was correct, but a Varied Thrush was the surprise. It didn't recover in the back yard, as the Swainson's Thrush had, but in the dark of a cardboard box in the den.

I telephoned Dr. Houston to enquire about banding a Varied Thrush. His response was very positive but skeptical about the thrush's recovery. Recover it did! A few minutes after Dr. Houston arrived, the thrush began flying around the den. The adult male ween the meadowlarks, Sturnella. Systematic Zoology 21:313-338.

${ }^{6}$ ROHWER, S.A. 1973. Significance of sympatry to behaviour and evolution of Great Plains meadowlarks. Evolution 27:44-57.

'TAYLOR, P. 1983. Wings along the Winnipeg: the birds of the Pinawa - Lac du Bonnet region, Manitoba. Eco Series No. 2, Manitoba Naturalists Society, Winnipeg, pp. 171-172.

Varied Thrush was photographed, banded and released.

Varied Thrushes have been reported several times in the Blue Jay but observing one close at hand and photographing a lifer is something else.

Why was Dr. Houston interested in banding the Varied Thrush? It was his two hundredth species banded. Congratulations!!

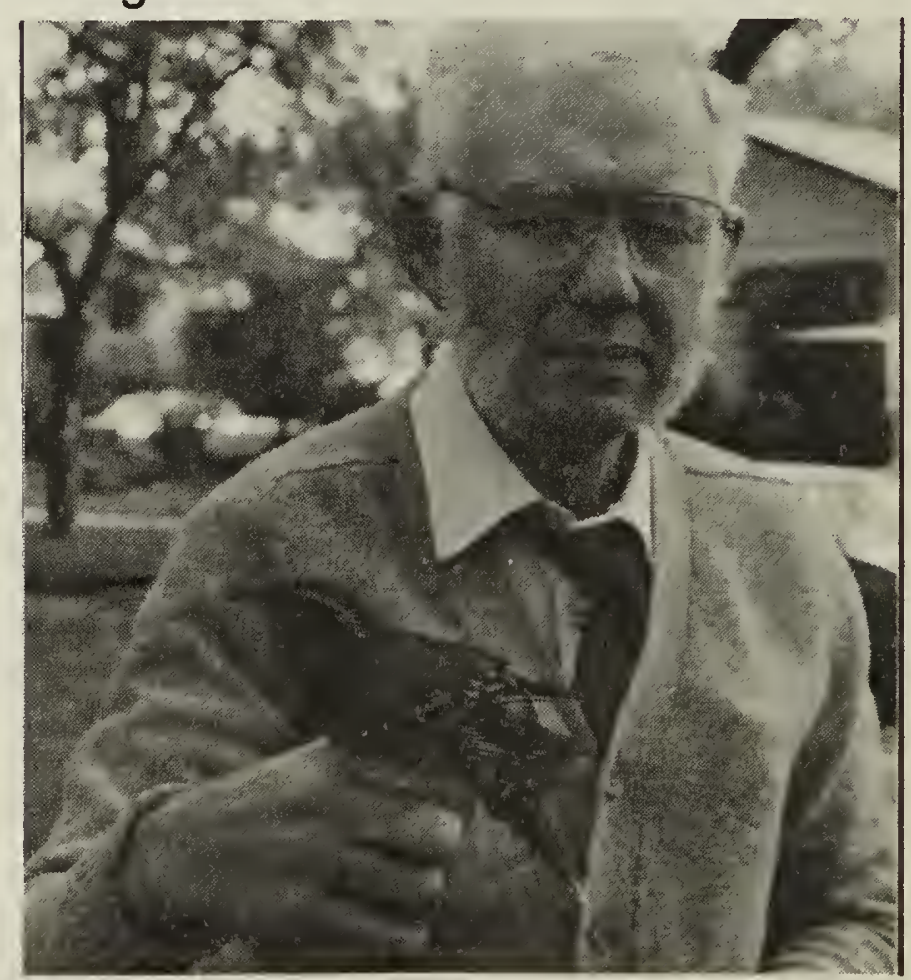

C. Stuart Houston with 200th species banded

$R$. Jensen 